\title{
Tissue remodeling by invadosomes
}

\author{
Alessandra Cambi (iD) ${ }^{1 *}, \mathrm{X} \quad$ Philippe Chavrier (iD) ${ }^{2 *, X}$ \\ ${ }^{1}$ Department of Cell Biology, Radboud Institute for Molecular Life Sciences, Radboud University Medical Center, Nijmegen, The Netherlands \\ ${ }^{2}$ Institut Curie, PSL Research University, CNRS UMR144, Paris, France \\ ${ }^{\mathrm{x}}$ These authors contributed equally to this work
}

\begin{abstract}
One of the strategies used by cells to degrade and remodel the extracellular matrix (ECM) is based on invadosomes, actin-based force-producing cell-ECM contacts that function in adhesion and migration and are characterized by their capacity to mediate pericellular proteolysis of ECM components. Invadosomes found in normal cells are called podosomes, whereas invadosomes of invading cancer cells are named invadopodia. Despite their broad involvement in cell migration and in protease-dependent ECM remodeling and their detection in living organisms and in fresh tumor tissue specimens, the specific composition and dynamic behavior of podosomes and invadopodia and their functional relevance in vivo remain poorly understood. Here, we discuss recent findings that underline commonalities and peculiarities of podosome and invadopodia in terms of organization and function and propose an updated definition of these cellular protrusions, which are increasingly relevant in patho-physiological tissue remodeling.
\end{abstract}

\section{Keywords}

Invadosome, invadopodium, podosome, actin cytoskeleton, cell migration

\section{Peer Review}

The peer reviewers who approve this article are:

1. Alissa Weaver, Department of Cell and Developmental Biology, Vanderbilt University Medical Center, Nashville, TN 37232 USA

Competing interests: No competing interests were disclosed.

2. Laura Machesky, Cancer Research UK Beatson Institute, College of Medical. Veterinary and Life Sciences, University of Glasgow, Glasgow, UK

Competing interests: No competing interests were disclosed.

3. Frédéric Saltel, INSERM, UMR1053, BaRITOn Bordeaux Research in Translational Oncology, 146 Rue Léo Saignat, Bordeaux, F-33000, France

Competing interests: No competing interests were disclosed. 
*Corresponding author: Alessandra Cambi (alessandra.cambi@radboudumc.nl); Philippe Chavrier (philippe.chavrier@curie.fr)

Competing interests: The authors declare that they have no competing interests.

Grant information: Funding for this work was provided by Fondation ARC pour la Recherche sur le Cancer (PGA1 RF20170205408) and Fondation Ruban Rose (Prix Avenir 2018) to PC. AC acknowledges financial support by Radboudumc Intramural funding.

The funders had no role in study design, data collection and analysis, decision to publish, or preparation of the manuscript.

Copyright: (C) 2021 Cambi A et al. This is an open access article distributed under the terms of the Creative Commons Attribution License, which permits unrestricted use, distribution, and reproduction in any medium, provided the original work is properly cited.

How to cite this article: Cambi A and Chavrier P. Tissue remodeling by invadosomes. Faculty Reviews 2021 10:(39) https://doi. org/10.12703/r/10-39

Published: 16 Apr 2021, Faculty Reviews 10:(39) https://doi.org/10.12703/r/10-39 


\section{Introduction}

Tissue remodeling is the (patho)physiological reorganization or renewal of existing tissues and consists of changes in extracellular matrix (ECM) composition and architecture and ensuing cellular responses. Many cells degrade and remodel the ECM using invadosomes, which are actin-based force-producing cell-ECM contacts functioning in adhesion and migration ${ }^{1}$. Characterized by their capacity to mediate pericellular proteolysis of ECM components, the invadosomes formed by non-transformed cells are called podosomes ${ }^{2,3}$, whereas invadosomes of invading cancer cells are named invadopodia ${ }^{4}$. These structures are broadly involved in cell migration and in the protease-dependent invasion program of tumor cells and have been detected in living organisms and in fresh tumor tissue specimens $^{5-7}$. Tumor molecular subtypes and the microenvironment await more systematic analyses to determine whether the capacity to form ECM-degradative invadopodia is a generic trait of all invasive metastatic cells and whether the intensity of the invadopodia response varies depending on the cancer type.

Podosomes and invadopodia likewise consist of a core of branched actin filaments, depending on N-WASP/WASP-mediated activation of the Arp2/3 complex, are sensitive to the substrate's stiffness, and recruit matrix metalloproteinases (MMPs), mainly the trans-membrane membrane type I (MT1)-MMP and the secreted MMP2 and MMP9, to degrade the ECM ${ }^{1,4,7-9}$. On the other hand, podosomes and invadopodia differ in their lifetime (over 1 hour for invadopodia as compared with minutes for podosomes) and in the repertoire of upstream activators of N-WASP/WASP-Arp2/3 stimulation ${ }^{10}$, which also suggests differences in regulation, molecular composition, and overall architecture. It should be noted, however, that podosomes of non-cancer cells can be involved in diseases. A typical example is the involvement of osteoclast podosomes in osteoporosis ${ }^{11}$. A detailed understanding of podosome- and invadopodia-specific mechanisms driving organization and function could therefore reveal new targets to better control unwanted invadosome-mediated pathologies.

In this review, we will discuss recent findings that underline common and specific traits/features of podosome and invadopodia organization and function, highlight the increasingly relevant role of invadosomes in tissue remodeling in many different patho-physiological processes, and propose an updated definition of these actin-rich protrusions.

\section{Podosomes and invadopodia: the Good and the Bad (and the Ugly)}

Identified back in 1985 as "cellular feet" at the adherent membrane of virus-transformed fibroblasts ${ }^{12}$, podosomes have been increasingly reported to form in a large variety of cell types such as leukocytes, osteoclasts, endothelial cells, and megakaryocytes ${ }^{1}$. In addition, ECM degradation-competent podosome-like structures have been recently identified in the neuromuscular junctions in vertebrate muscle cells ${ }^{13}$ and even in the parasite Entamoeba histolytica, which uses them to facilitate colonic tissue invasion ${ }^{14}$. Characterized by their round shape, individual podosomes $(\sim 0.5-1 \mu \mathrm{m} \varnothing)$ consist of a central core enriched in actin and actin-binding proteins surrounded by a ring of adhesion receptors and cytoskeletal scaffolding and signaling components (Figure 1A). Depending on the cell type, multiple individual podosomes are spatially organized in large assemblies acting as mechanosensing platforms in dendritic cells, as belts in osteoclasts, and as rosettes in endothelial cells ${ }^{2}$.

Podosome formation and activity are associated with several pathophysiological processes in which matrix degradation plays an important role. For example, endothelial podosomes are involved in angiogenesis by breaching the basement membrane and allowing new cell-cell interactions that are key to vascular remodeling ${ }^{15-17}$. In the bone, osteoclast podosomes contribute to physiological bone matrix remodeling as well as osteoporosis, which is due to excessive osteoclast activity ${ }^{11,18}$. A podosomebased specialized structure called the sealing zone is used by osteoclasts to adhere on bone and delimit the bone-resorbing are ${ }^{19}$. Targeting podosome formation and spatial organization in hyperactive osteoclasts is therefore proposed as a promising strategy to limit pathological osteolysis. Indeed, targeting the formation of the sealing zone via pharmacological inhibition of Dock5, a guanine nucleotide exchange factor for the small GTPase Rac, has been shown to prevent pathological bone loss while preserving bone formation in three mouse models for the most common osteolytic diseases ${ }^{11}$. Moreover, the use of fullerenol nanoparticles has been reported to suppress osteoclast differentiation and inhibit the formation of the sealing zone by blocking the formation and patterning of podosomes, making these nanoparticles interesting therapeutic agents against osteoporosis ${ }^{20}$. Antigen-presenting cells use podosomes for migration and mechanosensing, for breaching of the basement membrane, and possibly for aiding pathogen capture $^{8,21,22}$. Podosomes and podosome assemblies are sensitive to the topography of the extracellular environment, as they become linear-shaped when formed against fibrillar collagen $^{23}$ and can align and almost fuse when following substrate grooves ${ }^{24}$. Moreover, in dendritic cells, podosome clusters act as mechanosensing platforms ${ }^{22}$, and nanoscale rearrangements of individual podosome actin architecture as well as different ECM-degrading capacities are observed in response to changes in substrate stiffness ${ }^{25}$.

Basement membranes and the bone matrix are two-dimensional (2D) surfaces in the body, which justifies the use of classical cell culture plates and 2D substratum to investigate invadosome formation and dynamics. Seemingly, invasive tumor cells are exposed to and can breach 2D ECM constructs, such as the basement membrane separating the epithelium from the stroma of any given epithelial tissue and the endothelial basement membrane during the intravasation/extravasation steps of their metastatic journey. While we increasingly understand the molecular structure of invadosomes formed on 2D surfaces, more complex is the investigation of invadosomes in a three-dimensional (3D) environment, since their characteristic architecture changes into ECM-degrading globular assemblies 


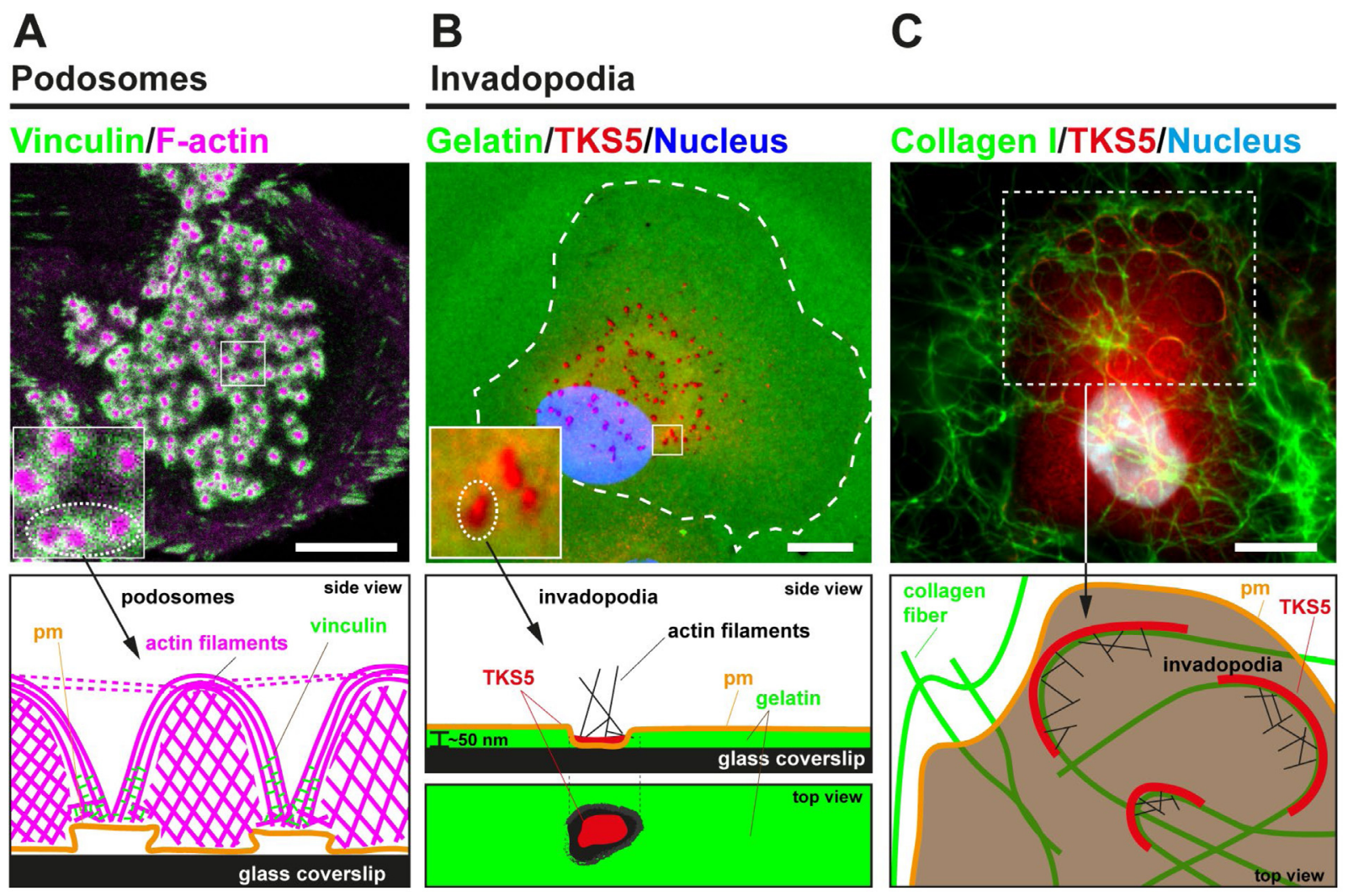

Figure 1. Podosome and invadopodia basics. (A) The upper image represents a human monocyte-derived immature dendritic cell that was plated for 60 minutes on a glass coverslip, fixed, and stained for actin (magenta) and vinculin (green). A large cluster of dotshaped podosomes is visible at the adherent surface. The lower panel schematically depicts the side view of a few individual podosomes, highlighting the different actin architectures. (B) In the upper image, MDA-MB-231 cells expressing TKS5GFP were plated for 60 minutes on a thin substratum of fluorescently labeled cross-linked gelatin (pseudocolored in green). Fixed cells were stained for GFP (pseudocolored in red), and the nucleus was stained with DAPI (pseudocolored in blue). Breast cancer cells form typical punctate gelatinolytic invadopodia enriched in the scaffolding protein TKS5. The lower panel schematically depicts a punctate invadopodium with TKS5 enrichment leading to the formation of a small F-actin patch lying on top of a region of gelatin degradation. (C) Upper image: MDA-MB-231 cells expressing TKS5GFP were plated for 60 minutes on a thick layer of fluorescently labeled fibrillar type I collagen (pseudocolored in green). Cells were stained for GFP (pseudocolored in red), and the nucleus was stained with DAPI (pseudocolored in blue). The lower panel schematizes elongated TKS5-, F-actin-rich invadopodia forming at contact sites with the collagen fibers. Scale bars, $10 \mu \mathrm{m}$. pm, plasma membrane.

at the extremity of cellular protrusions, as observed in dendritic cells, macrophages, or invasive cancer cells in 3D collagen gels $^{26-28}$. Unraveling the environment-dependent composition, dynamic properties, and function of $3 \mathrm{D}$ invadosomes in relation to cell migration and tissue remodeling is the current challenge.

\section{Podosome vs. invadopodia organization: Beauty and the Beast}

Several studies explored the organization of tumor cell invadopodia in relation with two vs. three environment dimensionalities. In the classical still-useful model to study invadopodia, cancer-derived cell lines or freshly isolated tumor cells from patients are plated on a 2D substratum of fluorescently labeled gelatin (denatured type I collagen) where degradative activity is concentrated in $0.5-1 \mu \mathrm{m}$ diameter, cortactin/F-actin-rich dot-like invadopodia ${ }^{29}$ (Figure 1B). Although these structures have been broadly designated as protrusive invadopodia, electron microscopy analysis has revealed that the thickness of the crosslinked gelatin coat is typically $50-100 \mathrm{~nm}^{30,31}$, thus leaving limited space for protrusive activity (as a reminder, the plasma membrane is typically $\sim 10 \mathrm{~nm}$ thick and the lamellipodial actin meshwork is several hundred nm wide). Possibly more relevant evidence for protrusive invadopodia came from the observation of breast or colon carcinoma cells plated on a layer of Matrigel, which polymerizes to form a hydrogel of composition resembling the basement membrane, deposited on the surface of a porous polycarbonate filter ${ }^{32}$. However, in this experimental construct, it was arduous to distinguish mature ECM-degrading invadopodia from protruding F-actin/ cortactin-based lamellipodial structures filling the empty space in the filter pores. In addition, because Matrigel lacks native 
covalent crosslinks, the implication of MMPs-and invadopodia-in the penetration of tumor cells through Matrigel could be questionable ${ }^{33,34}$.

Using a thick (4-5 $\mu \mathrm{m}$ thick), cell-derived matrix construct consisting of a densely packed fibrillar type I collagen matrix, scientists reported numerous puncta-like invadopodia at the adherent surface of MDA-MB-231 breast cancer cells ${ }^{35,36}$. However, when exposed to a sparser fibrous network of acid-extracted native type I collagen, cancer cells including MDA-MB-231 cells formed elongated invadopodia, up to several microns in length, in close apposition to and fitting the shape of the matrix fibers $^{23,37,38}$ (Figure 1C). Whether these elongated proteolytically active invadopodia are formed by the coalescence of smaller individual structures assembling in different sites along the fibers is presently unknown. When visualized in cancer cells invading within a 3D fibrillary collagen gel, elongated invadopodia formed as rings (or ring segments), which circled the leading cell protrusion extending in front of the nucleus and assembled in intimate contact with constricting matrix pores $^{28,38-40}$. Collagen cleavage, based on MT1-MMP activity, in conjunction with the production of outward forces using the energy of actin polymerization at the level of the invadopodia ${ }^{38,41}$, have been shown to drive invadopodia expansion in this system and, thus, to push the matrix fibers aside to facilitate nuclear and cell penetration ${ }^{38}$. Therefore, while, by definition, all invadopodia types degrade the matrix, their organization, activity, and dynamics differ depending on the composition, density, and mechanical properties of the matrix, at least in vitro ${ }^{36,42,43}$.

A common theme to both podosomes and invadopodia is that these structures are designed to maintain intimate and prolonged contacts between surface-exposed MT1-MMP accumulated in the invadosome plasma membrane and the underlying matrix substrates to ensure optimal exploration and penetration of the pericellular tissues. Invadosomes are built upon a network of branched actin filaments depending on the activity of the Arp2/3 complex, which initiates branched actin filament growth from the sides of pre-existing mother filaments. A high degree of organization of this network is necessary to optimize the relationship between actin assembly and local production of pushing forces ${ }^{44}$. Along this line, several recent reports based on super-resolution microscopy highlighted a complex organization of a two-component actin network in the protrusive actin-core of individual podosomes ${ }^{2,25,45}$ (Figure 2A-C). As a result, these auto-assemblies function as micron-sized protrusive machineries ${ }^{46-48}$. In addition, interconnectivity of neighboring podosomes through a radiating network of actin filament bundles provides a higher-order organization, which ensures exploration of the pericellular matrix at a mesoscale level ${ }^{22,25}$. Protrusive forces in the $\mathrm{pN}$ range have been measured at the level of podosomes in macrophages based on the deformation of a compliant sheet of polyvinyl formal resin (see 2 and references herein). Interestingly, direct measurement of forces in the integrin receptors accumulating in the adhesion ring surrounding the podosome actin core using DNA-based FRET-FLIM probes revealed forces also in the $\mathrm{pN}$ range ${ }^{49}$. All together, these findings suggest that podosome protrusion forces may be counterbalanced by local traction forces at the podosome ring ${ }^{2}$.

By comparison to the podosome's exquisite organization ${ }^{50,51}$, recent ultrastructure analysis by platinum replica electron microscopy revealed a rather rudimentary invadopodia architecture, consisting of a $\sim 200-300 \mathrm{~nm}$ array of Arp2/3 branched actin filaments with their (+)-ends facing the plasma membrane/collagen fiber contact zone $^{38}$ (Figure 2). Despite a simple actin meshwork organization, invadopodia can efficiently push collagen fibers away using energy from Arp2/3 complex-dependent actin polymerization ${ }^{38}$. Additionally, it was recently reported that seemingly rudimentary punctate invadopodia forming on the $2 \mathrm{D}$ gelatin matrix construct exert $\mathrm{pN}$ forces towards the substratum ${ }^{41}$. In elongated collagenolytic invadopodia, pushing forces seem to be assisted by the curvature of the actin meshwork and contacting matrix fiber, increasing frictional forces between individual actin filaments in the meshwork. Additionally, enzymatic cleavage of the matrix fibers by MT1-MMP increased matrix compliance and facilitated fiber displacement ${ }^{38}$. Interestingly, the collagen type I receptor discoidin domain receptor 1 (DDR1) has been reported to accumulate at the surface of cells derived from breast, lung, and liver cancer at contact sites with the surrounding collagen fibers ${ }^{52,53}$. Moreover, DDR1 was required for the formation of linear matrix-degradative invadopodia by these cell lines, suggesting a role for this collagen receptor in the binding and/ or recognition of the collagen fibers leading to invadopodia formation $^{52,53}$. However, contrasting with these reports, forced expression of the DDR1 receptor was found to inhibit invadopodia formation by mesenchymal (DDR1-negative) and highly invasive MDA-MB-231 breast cancer cells, while silencing of DDR1 in breast epithelial MCF10DCIS cells promoted collagenolytic invadopodia ${ }^{38}$. Of note, MT1-MMP, which can also interact with the collagen fibers through its extracellular hemopexin domain, was found to be required for the formation of invadopodia by breast tumor cells ${ }^{38,52,53}$. Therefore, more work will be required to decipher the roles played by collagen receptors including MT-MMP, DDRs, and integrins in ECM remodeling by cancer cells.

\section{Invadosomes in real life}

Although invadopodia have been functionally linked to processes involving ECM remodeling based on numerous studies using tumor cells cultured in vitro and tumor cell implantation models, data documenting the existence and activity of invadopodia structures in human tumor specimens using classical, typically low-resolution imaging approaches such as immunohistochemistry on paraffin-embedded or frozen tissue sections have proven elusive. Yet the expression levels of MT1-MMP and several invadopodial components, including the key invadopodia scaffolding protein, Tks5, have been linked with poor clinical outcome in various cancers ${ }^{1,54}$. Along this line, in breast 

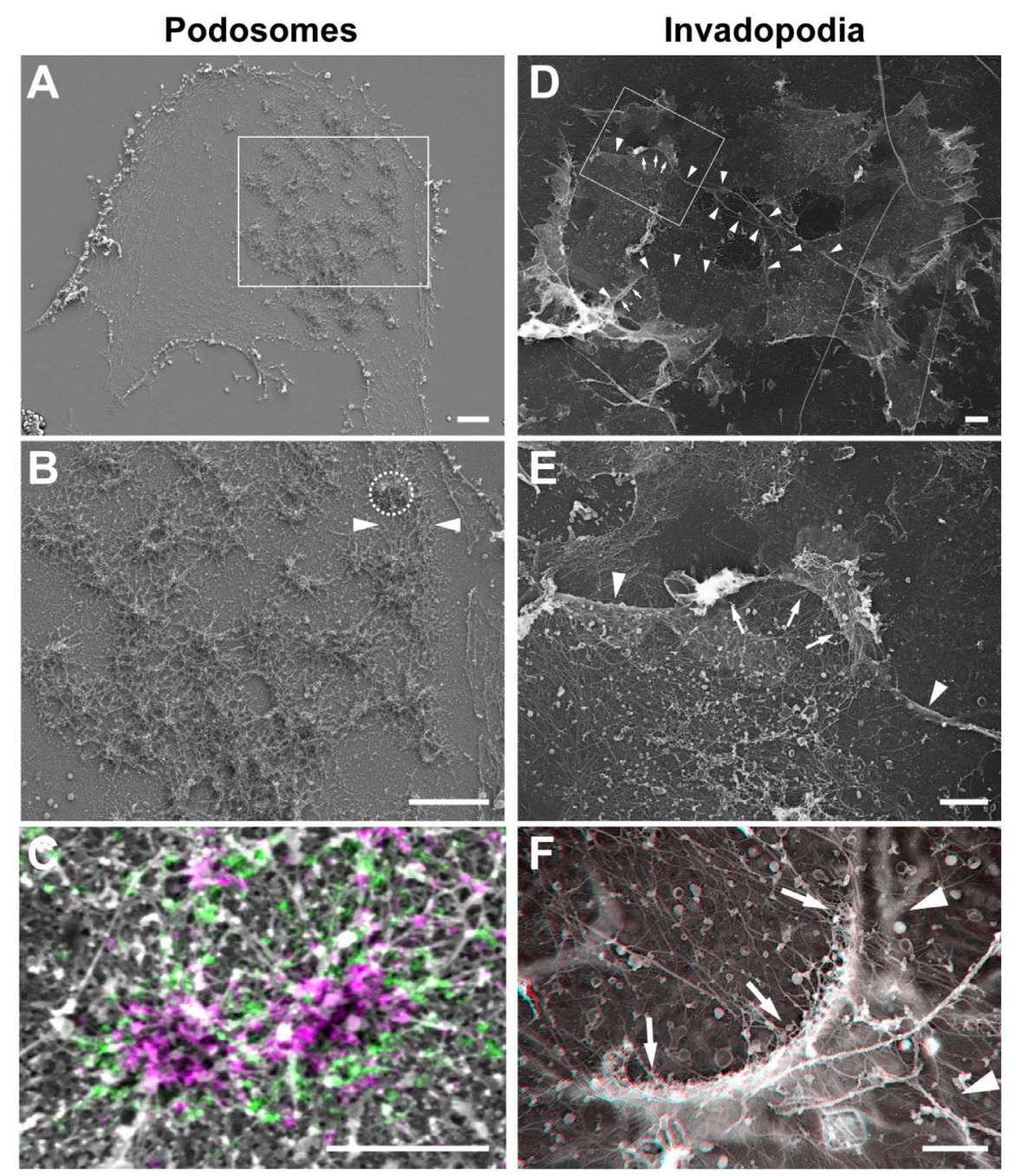

Figure 2. Correlative light and electron microscopy reveals the ultrastructural organization of invadopodia and podosomes. (A, B) Dendritic cells were seeded on glass coverslips, unroofed by sonication, and quickly fixed leaving ventral plasma membranes (VPMs) exposing the cytosolic side of the membrane including podosomes. After critical point drying, the VPMs were imaged by scanning electron microscopy (SEM) (gray). The core structure of a podosome is circled by a dashed line in panel B. Arrowheads depict inter-podosome F-actin bundles. (C) Fixed VPMs were stained for vinculin (green) and zyxin (purple), imaged by stochastic optical reconstruction microscopy and subsequently by SEM (gray). (D) Platinum replica electron microscopy survey view of the cytoplasmic surface of the adherent plasma membrane in unroofed MDA-MB-231 cells plated for 60 minutes on a thin layer of collagen I (image is inverted). (E) Zoomed-in region corresponding to the boxed region in panel $\mathbf{D}$. (F) High-magnification view of an invadopodium in association with a curved collagen fiber. For (F), use view glasses for 3D viewing of anaglyphs (left eye, red). Arrows point to invadopodia appearing as bow-shaped electron-dense proteinaceous material in association with the plasma membrane above a collagen fiber. Arrowheads depict collagen fibers underneath the VPM. Scale bars: $2 \mu \mathrm{m}$ (panels $\mathbf{A}, \mathbf{B}, \mathbf{D}$, and $\mathbf{E}$ ) and $1 \mu \mathrm{m}$ (panels $\mathbf{C}$ and $\mathbf{F}$ ).

cancer, elevated MT1-MMP expression is required for the transition from non-disseminated in situ tumors to invasive carcinomatous lesions, requiring transmigration of carcinoma cells across the basement membrane, and is associated with higher metastatic risk ${ }^{54-56}$. In addition, genuine invadopodia structures have been observed in freshly explanted primary human tumor cells ${ }^{7}$. Collectively, these data imply a threatening role for invadopodia and their sword arm, MT1-MMP, during cancer dissemination and metastasis ${ }^{57}$. The difficulty to provide direct evidence of invadopodia occurrence in human tumors is probably related to their small size and transient nature and the lack of dedicated markers to unambiguously 
identify invadopodia. In this respect, the recent immunohistochemical detection of the exclusive podosome/invadopodia marker, TKS5, in patient tumor specimens represents a significant promising $\mathrm{step}^{6,58}$. Given the pivotal role of invadopodia in cancer cell dissemination, drugs able to counteract their function could be highly valuable for the prevention of cancer metastasis. Several reviews already detail the failure of small molecule pan-MMP inhibitors (for instance, see 59), leading to the conclusion that inhibitors with better selectivity and new strategies including targeted delivery are in need. Among the new MMP inhibitors, function-blocking antibodies directed against MT1-MMP have been developed and are characterized in preclinical studies ${ }^{60,61}$. Proof-of-concept unbiased screening approaches pioneered by the Courtneidge lab also successfully identified small molecules targeting invadopodia formation and function, including promising CDK5 and TAO3 kinase inhibitors $^{62,63}$.

In the past few years, intravital microscopy of tumor cells expressing fluorescently tagged invadopodia markers offered an alternative powerful approach, and evidence for the existence of invadopodia in various genetically defined mouse cancer models has been accumulating. Intravital imaging of orthotopic mammary tumor xenografts expressing cytosolic GFP or GFP-labeled cytoskeleton and invadopodial components, cortactin, or coronin-1C revealed mostly protrusive globular structures forming at the invasive front of the cells, some of them in close proximity with interstitial type I collagen bundles detected by second harmonic generation ${ }^{64-68}$. In some of these studies, injection of an activatable fluorescent MMP biosensor (MMPSense) in the mouse vasculature revealed an association of cortactin-enriched protrusions with MMP activity and ascertain that these structures were proteolytically active invadopodia associated with tumor-disseminating cells ${ }^{65}$. In addition to providing compelling evidence that invadopodia contribute to the stromal dissemination of tumor cells, high-resolution intravital imaging using a chick embryo chorioallantoic membrane model also demonstrated that cancer cells exploit invadopodia to breach the endothelium during extravasation ${ }^{69}$. Very recently, tumor cell dissemination has been imaged, with actin- and cortactin-rich invasive protrusions found to be associated with degradation of the ECM and the visceral muscle layer in the native context of the Drosophila midgut ${ }^{70}$, once again highlighting the importance of simple model organisms to investigate cancer invasion.

Compared to invadopodia, podosomes in vivo are less well documented and imaging of their formation and dynamics in living mice by intravital microscopy is still lacking. However, several pioneering studies have provided convincing evidence of podosome formation in vivo. For example, the development of an ex vivo endothelium observation model enabled visualization of podosome rosettes and their basement membrane degradative capacity in native aortic vessel segments previously exposed to biologically active TGF $\beta$ and harvested from mice after intraventricular cardiac injection of fixative ${ }^{17}$. The presence of podosomes in mice aortas was also determined in vascular smooth muscle cells lacking microRNA-143/145, in which circular structures composed of cortactin and Tks5 were visualized by immunoelectron microscopy ${ }^{71}$. More recently, a combination of fluorescence, electron, and three-dimensional microscopy was used to image the contacts between megakaryocytes and endothelial cells in mouse bone marrow sections, revealing that megakaryocytes use in vivo podosome-like structures that collectively allow the penetration into the endothelium of bone marrow sinusoids ${ }^{72}$. Finally, elegant work in living Caenorhabditis elegans larvae showed the formation of invadosomes in the anchor cell and their role in basement membrane remodeling during vulval development ${ }^{5,73}$.

To better understand invadosome structure and organization in a native tissue, one would ideally want an imaging technique that allows you to obtain macroscopic views of tissues and organs and at the same time to conveniently zoom into these subcellular structures at very high resolution directly in (living) organisms. With the fast pace at which the microscopy field is moving in combination with new dedicated animal models ${ }^{74}$, we expect exciting discoveries in this direction in the near future.

\section{A revised definition of invadosomes: the Transformers of cell protrusion}

The term invadosomes collectively indicates two groups of cell protrusions, podosomes and invadopodia, that share many similarities but also exhibit specific traits. Considering the most recent findings in the field, we here attempt to provide an updated set of criteria that could help define these structures. We propose minimal requirements (i.e. positivity for cortactin and F-actin) and recently identified properties (i.e. mesoscale organization for podosomes ${ }^{22}$ or location underneath the nucleus for invadopodia ${ }^{28,31}$ ) as new criteria that should help classify a protrusion as either a podosome or an invadopodium. Considering the plasticity of invadosome structures, which include dot-like invasive protrusions as well as plasma membrane-matrix fiber contact sites with linear features, the presence of membrane protrusions could be considered as an optional criterion to classify invadosomes. However, the detailed architecture at the individual invadosome and at the cluster level is still lacking, and properties such as dynamic behavior, mechanosensitivity, and behavior in a 3D context surely need more investigation. Moreover, invadosomes are not restricted to cell migration and matrix remodeling. In fact, cellular protrusions containing typical invadosome components have also been identified in myoblast fusion ${ }^{75}$ and immune synapse formation $^{76}$ as well as phagocytosis events ${ }^{77}$, highlighting the great plasticity of this system. We therefore expect that novel insight into the function and architecture of invadosomes and their involvement in specific cellular processes will further sharpen the definition criteria proposed here.

The role of invadosomes in tissue remodeling is becoming increasingly clear, but open questions remain. In the osteoclasts, 
for example, podosomes mediate degradation of the organic part of the bone matrix, leading to the release of molecules such as growth factors and other chemical signals that can affect the activity of surrounding osteoblasts. For invadopodia, however, the impact of their ECM degradation on cells surrounding the tumor, such as stromal cells or immune cells, remains to be established. In addition, efforts should be made to link the initial mechanobiology findings on podosomes and invadopodia to real pathophysiological situations in tissues, such as understanding how invadosomes respond to local ECM stiffening as found in fibrotic tissues or at interfaces with regenerative biomaterials.

\section{Acknowledgements}

The authors apologize to the many colleagues whose work could not cited because of space restrictions. The authors would like to thank D. Remy and R. Ferrari (Institut Curie, PSL Research University, Paris, France) for the immunofluorescence images, S. Vassilopoulos (Institute of Myology, Paris, France) for the electron microscopy image of invadopodia, and B. Joosten and K. van den Dries (Radboud University Medical Center, Nijmegen, The Netherlands) for the CLEM image of podosomes, and all the members of the Cambi and Chavrier labs for discussions.
1. Paterson EK, Courtneidge SA: Invadosomes are coming: New insights into function and disease relevance. FEBS J. 2018; 285(1): 8-27. PubMed Abstract | Publisher Full Text | Free Full Text | Faculty Opinions Recommendation

2. Vvan den Dries K, Linder S, Maridonneau-Parini I, et al.: Probing the mechanical landscape - new insights into podosome architecture and mechanics. J Cell Sci. 2019; 132(24): jcs236828. PubMed Abstract | Publisher Full Text | Faculty Opinions Recommendation

3. Varon C, Tatin F, Moreau V, et al:: Transforming growth factor beta induces rosettes of podosomes in primary aortic endothelial cells. Mol Cell Biol. 2006; 26(9): 3582-94.

PubMed Abstract | Publisher Full Text | Free Full Text

4. Eddy RJ, Weidmann MD, Sharma VP, et al.: Tumor Cell Invadopodia: Invasive Protrusions that Orchestrate Metastasis. Trends Cell Biol. 2017; 27(8): 595-607. PubMed Abstract | Publisher Full Text | Free Full Text

5. Kelley LC, Chi Q, Cáceres R, et al.: Adaptive F-Actin Polymerization and Localized ATP Production Drive Basement Membrane Invasion in the Absence of MMPs. Dev Cell. 2019; 48(3): 313-328.e8. PubMed Abstract | Publisher Full Text | Free Full Text | Faculty Opinions Recommendation

6. Chen YC, Baik M, Byers JT, et al.: TKS5-positive invadopodia-like structures in human tumor surgical specimens. Exp Mol Pathol. 2019; 106 17-26.

PubMed Abstract | Publisher Full Text | Free Full Text |

Faculty Opinions Recommendation

7. Clark ES, Whigham AS, Yarbrough WG, et al:: Cortactin is an essential regulator of matrix metalloproteinase secretion and extracellular matrix degradation in invadopodia. Cancer Res. 2007; 67(9): 4227-35. PubMed Abstract | Publisher Full Text

8. El Azzouzi K, Wiesner C, Linder S: Metalloproteinase MT1-MMP islets act as memory devices for podosome reemergence. J Cell Biol. 2016; 213(1): 109-25. PubMed Abstract | Publisher Full Text | Free Full Text

9. Castro-Castro A, Marchesin V, Monteiro $\mathrm{P}$, et al.: Cellular and Molecular Mechanisms of MT1-MMP-Dependent Cancer Cell Invasion. Annu Rev Cell Dev Biol. 2016; 32: 555-76.

PubMed Abstract | Publisher Full Text | Faculty Opinions Recommendation

10. Oser M, Dovas A, Cox D, et al.: Nck1 and Grb2 localization patterns can distinguish invadopodia from podosomes. Eur J Cell Biol. 2011; 90(2-3): 181-8. PubMed Abstract | Publisher Full Text | Free Full Text

11. Vives V, Cres G, Richard C, et al:: Pharmacological inhibition of Dock5 prevents osteolysis by affecting osteoclast podosome organization while preserving bone formation. Nat Commun. 2015; 6: 6218 .

PubMed Abstract | Publisher Full Text

12. Tarone G, Cirillo D, Giancotti FG, et al.: Rous sarcoma virus-transformed fibroblasts adhere primarily at discrete protrusions of the ventral membrane called podosomes. Exp Cell Res. 1985; 159(1): 141-57. PubMed Abstract | Publisher Full Text

13. C Chan ZCK, Kwan HLR, Wong YS, et al:: Site-directed MT1-MMP trafficking and surface insertion regulate AChR clustering and remodeling at developing NMJs. eLife. 2020; 9: e54379.

PubMed Abstract | Publisher Full Text | Free Full Text |

Faculty Opinions Recommendation
14.

Hasan MM, Teixeira JE, Huston CD: Invadosome-Mediated Huma Extracellular Matrix Degradation by Entamoeba histolytica. Infect Immun. 2018; 86(9): e00287-18.

PubMed Abstract | Publisher Full Text | Free Full Text |

Faculty Opinions Recommendation

15. Alonso F, Spuul P, Génot E: Podosomes in endothelial cell-microenvironment interactions. Curr Opin Hematol. 2020; 27(3): 197-205. PubMed Abstract | Publisher Full Text | Faculty Opinions Recommendation

16. Alonso F, Spuul P, Decossas M, et al:: Regulation of podosome formation in aortic endothelial cells vessels by physiological extracellular cues. Eur $\mathrm{J}$ Cell Biol. 2020; 99(4): 151084

PubMed Abstract | Publisher Full Text | Faculty Opinions Recommendation

17. Rottiers $\mathrm{P}$, Saltel F, Daubon T, et al:: TGFbeta-induced endothelial podosomes mediate basement membrane collagen degradation in arterial vessels. $J$ Cell Sci. 2009; 122(Pt 23): 4311-8. PubMed Abstract | Publisher Full Text

18. Mascarau R, Bertrand F, Labrousse A, et al.: HIV-1-Infected Human Macrophages, by Secreting RANK-L, Contribute to Enhanced Osteoclast Recruitment. Int J Mol Sci. 2020; 21(9): 3154. PubMed Abstract | Publisher Full Text | Free Full Text | Faculty Opinions Recommendation

19. Touaitahuata $\mathrm{H}$, Blangy A, Vives V: Modulation of osteoclast differentiation and bone resorption by Rho GTPases. Small GTPases. 2014; 5: e28119. PubMed Abstract | Publisher Full Text | Free Full Text

20. Chen $\mathrm{K}$, Geng $\mathrm{H}$, Liang W, et al:: Modulated podosome patterning in osteoclasts by fullerenol nanoparticles disturbs the bone resorption for osteoporosis treatment. Nanoscale. 2020; 12(17): 9359-65. PubMed Abstract | Publisher Full Text

21. Baranov M, Beest MT, Reinieren-Beeren I, et al:: Podosomes of dendritic cells facilitate antigen sampling. J Cell Sci. 2014; 127(Pt 5): 1052-64. PubMed Abstract | Publisher Full Text | Free Full Text

22. Meddens MBM, Pandzic E, Slotman JA, et al:: Actomyosin-dependent dynamic spatial patterns of cytoskeletal components drive mesoscale podosome organization. Nat Commun. 2016; 7: 13127. PubMed Abstract | Publisher Full Text | Free Full Text Faculty Opinions Recommendation

23. Juin A, Billottet $\mathrm{C}$, Moreau V, et al:: Physiological type I collagen organization induces the formation of a novel class of linear invadosomes. Mol Biol Cell. induces the formation PubMed Abstract | Publisher Full Text | Free Full Text

24. Joosten B, Willemse M, Fransen J, et al: Super-Resolution Correlative Light and Electron Microscopy (SR-CLEM) Reveals Novel Ultrastructural Insights Into Dendritic Cell Podosomes. Front Immunol. 2018; 9: 1908. PubMed Abstract | Publisher Full Text | Free Full Text

25. van den Dries K, Nahidiazar L, Slotman JA, et al:: Modular actin nanoarchitecture enables podosome protrusion and mechanosensing. Nat Commun. 2019; 10(1): 5171 . PubMed Abstract | Publisher Full Text | Free Full Text

26. Cougoule C, Lastrucci C, Guiet R, et al.: Podosomes, But Not the Maturation Status, Determine the Protease-Dependent 3D Migration in Human Dendritic Cells. Front Immunol. 2018; 9: 846 PubMed Abstract | Publisher Full Text | Free Full Text | Faculty Opinions Recommendation 
27. Van Goethem E, Poincloux R, Gauffre F, et al:: Matrix architecture dictates three-dimensional migration modes of human macrophages: Differential involvement of proteases and podosome-like structures. J Immunol. 2010; 184(2): 1049-61. PubMed Abstract | Publisher Full Text

28. Infante E, Castagnino A, Ferrari R, et al:: LINC complex-Lis1 interplay controls MT1-MMP matrix digest-on-demand response for confined tumor cell migration. Nat Commun. 2018; 9(1): 2443. PubMed Abstract | Publisher Full Text | Free Full Text | Faculty Opinions Recommendation

29. Linder S, Wiesner C, Himmel M: Degrading devices: Invadosomes in proteolytic cell invasion. Annu Rev Cell Dev Biol. 2011; 27: 185-211. PubMed Abstract | Publisher Full Text

30. Artym VV, Zhang Y, Seillier-Moiseiwitsch F, et al:: Dynamic interactions of cortactin and membrane type 1 matrix metalloproteinase at invadopodia: Defining the stages of invadopodia formation and function. Cancer Res. 2006; 66(6): 3034-43.

PubMed Abstract | Publisher Full Tex

31. Revach OY, Weiner A, Rechav K, et al: Mechanical interplay between invadopodia and the nucleus in cultured cancer cells. Sci Rep. 2015; 5: 9466. PubMed Abstract | Publisher Full Text | Free Full Text

32. S Schoumacher M, Goldman RD, Louvard D, et al.: Actin, microtubules, and vimentin intermediate filaments cooperate for elongation of invadopodia. $J$ Cell Biol. 2010; 189(3): 541-56.

PubMed Abstract | Publisher Full Text | Free Full Text |

Faculty Opinions Recommendation

33. S Sabeh F, Shimizu-Hirota R, Weiss SJ: Protease-dependent versus independent cancer cell invasion programs: Three-dimensional amoeboid movement revisited. $J$ Cell Biol. 2009; 185(1): 11-9. PubMed Abstract | Publisher Full Text | Free Full Text | Faculty Opinions Recommendation

34. Rowe RG, Weiss SJ: Breaching the basement membrane: Who, when and how? Trends Cell Biol. 2008; 18(11): 560-74. PubMed Abstract | Publisher Full Text

35. Artym VV, Swatkoski S, Matsumoto $\mathrm{K}$, et al.: Dense fibrillar collagen is a potent inducer of invadopodia via a specific signaling network. J Cell Biol. 2015; 208(3): 331-50. PubMed Abstract | Publisher Full Text | Free Full Text

36. lizuka S, Leon RP, Gribbin KP, et al.: Crosstalk between invadopodia and the extracellular matrix. Eur J Cell Biol. 2020; 99(7): 151122. PubMed Abstract | Publisher Full Text | Faculty Opinions Recommendation

37. Monteiro P, Rossé C, Castro-Castro A, et al.: Endosomal WASH and exocyst complexes control exocytosis of MT1-MMP at invadopodia. J Cell Biol. 2013; 203(6): 1063-79

PubMed Abstract | Publisher Full Text | Free Full Text |

Faculty Opinions Recommendation

38. Ferrari R, Martin G, Tagit O, et al:: MT1-MMP directs force-producing proteolytic contacts that drive tumor cell invasion. Nat Commun. 2019; 10(1): 4886. PubMed Abstract | Publisher Full Text | Free Full Text

39. Wolf $\mathrm{K}, \mathrm{Wu} \mathrm{YI}, \mathrm{Liu} \mathrm{Y}$, et al:: Multi-step pericellular proteolysis controls the transition from individual to collective cancer cell invasion. Nat Cell Biol. 2007 9(8): 893-904.

PubMed Abstract | Publisher Full Text | Faculty Opinions Recommendation

40. Wolf $\mathrm{K}, \mathrm{Te}$ Lindert $\mathrm{M}, \mathrm{Krause} \mathrm{M}$, et al:: Physical limits of cell migration: Control by ECM space and nuclear deformation and tuning by proteolysis and traction force. J Cell Biol. 2013; 201(7): 1069-84. PubMed Abstract | Publisher Full Text | Free Full Text | Faculty Opinions Recommendation

41. Dalaka E, Kronenberg NM, Liehm P, et al.: Direct measurement of vertical forces shows correlation between mechanical activity and proteolytic ability of invadopodia. Sci Adv. 2020; 6(11): eaax6912. PubMed Abstract | Publisher Full Text | Free Full Text | Faculty Opinions Recommendation

42. Alexander NR, Branch $\mathrm{KM}$, Parekh $\mathrm{A}$, et al.: Extracellular matrix rigidity promotes invadopodia activity. Curr Biol. 2008; 18(17): 1295-1299. PubMed Abstract | Publisher Full Text | Free Full Text

43. Branch KM, Hoshino D, Weaver AM: Adhesion rings surround invadopodia and promote maturation. Biol Open. 2012; 1(8): 711-22. PubMed Abstract | Publisher Full Text | Free Full Text

44. Mogilner A, Oster G: Cell motility driven by actin polymerization. Biophys $J$. 1996; 71(6): 3030-45 PubMed Abstract | Publisher Full Text | Free Full Text

45. Proag A, Bouissou A, Mangeat T, et al.: Working together: Spatial synchrony in the force and actin dynamics of podosome first neighbors. ACS Nano. 2015; 9(4): 3800-13. PubMed Abstract | Publisher Full Text

46. Bouissou A, Proag A, Bourg N, et al:: Podosome Force Generation Machinery: A Local Balance between Protrusion at the Core and Traction at the Ring. ACS
Nano. 2017; 11(4): 4028-4040.

PubMed Abstract | Publisher Full Text

47. Labernadie A, Thibault C, Vieu C, et al.: Dynamics of podosome stiffness revealed by atomic force microscopy. Proc Natl Acad Sci U S A. 2010; 107(49): 21016-21.

PubMed Abstract | Publisher Full Text | Free Full Text

48. van den Dries K, Meddens MBM, de Keijzer S, et al:: Interplay between myosin IIA-mediated contractility and actin network integrity orchestrates podosome composition and oscillations. Nat Commun. 2013; 4: 1412

PubMed Abstract | Publisher Full Text | Free Full Text

49. Glazier R, Brockman JM, Bartle E, et al.: DNA mechanotechnology reveals that integrin receptors apply $\mathrm{pN}$ forces in podosomes on fluid substrates. Nat Commun. 2019; 10(1): 4507.

PubMed Abstract | Publisher Full Text | Free Full Text |

Faculty Opinions Recommendation

50. A Akisaka T, Yoshida A: Scattered podosomes and podosomes associated with the sealing zone architecture in cultured osteoclasts revealed by cell shearing, quick freezing, and platinum-replica electron microscopy. Cytoskeleton (Hoboken). 2019; 76(4): 303-321.

PubMed Abstract | Publisher Full Text | Faculty Opinions Recommendation

51. Luxenburg C, Geblinger D, Klein E, et al.: The architecture of the adhesive apparatus of cultured osteoclasts: From podosome formation to sealing zone assembly. PLoS One. 2007; 2(1): e179.

PubMed Abstract | Publisher Full Text | Free Full Text

52. Juin A, Di Martino J, Leitinger B, et al.: Discoidin domain receptor 1 controls linear invadosome formation via a Cdc42-Tuba pathway. J Cell Biol. 2014; 207(4): 517-33

PubMed Abstract | Publisher Full Text | Free Full Text

53. Ezzoukhry $Z$, Henriet $E$, Piquet $L$, et al: TGF- $\mathbf{1}$ promotes linear invadosome formation in hepatocellular carcinoma cells, through DDR1 up-regulation and collagen I cross-linking. Eur J Cell Biol. 2016; 95(11): 503-512. PubMed Abstract | Publisher Full Text

54. Lodillinsky C, Infante E, Guichard A, et al.: p63/MT1-MMP axis is required for in situ to invasive transition in basal-like breast cancer. Oncogene. 2016; 35(3): situ to inva 34 .

PubMed Abstract | Publisher Full Text

55. Perentes JY, Kirkpatrick ND, Nagano S, et al:: Cancer cell-associated MT1-MMP promotes blood vessel invasion and distant metastasis in triple-negative mammary tumors. Cancer Res. 2011; 71(13): 4527-38. PubMed Abstract | Publisher Full Text

56. Feinberg TY, Zheng H, Liu R, et al.: Divergent Matrix-Remodeling Strategies Distinguish Developmental from Neoplastic Mammary Epithelial Cell Invasion Programs. Dev Cell. 2018; 47(2): 145-160.e6.

PubMed Abstract | Publisher Full Text | Free Full Text | Faculty Opinions Recommendation

57. Paz H, Pathak N, Yang J: Invading one step at a time: The role of invadopodia in tumor metastasis. Oncogene. 2014; 33(33): 4193-202. PubMed Abstract | Publisher Full Text | Free Full Text

58. Baik M, French B, Chen YC, et al:: Identification of invadopodia by TKS5 staining in human cancer lines and patient tumor samples. MethodsX. 2019; 6 : $718-26$

PubMed Abstract | Publisher Full Text | Free Full Text | Faculty Opinions Recommendation

59. Liu J, Khalil RA: Matrix Metalloproteinase Inhibitors as Investigational and Therapeutic Tools in Unrestrained Tissue Remodeling and Pathological Disorders. Prog Mol Biol Transl Sci. 2017; 148: 355-420. PubMed Abstract | Publisher Full Text | Free Full Text

60. Haage A, Nam DH, Ge X, et al:: Matrix metalloproteinase-14 is a mechanically regulated activator of secreted MMPs and invasion. Biochem Biophys Res Commun. 2014; 450(1): 213-8. PubMed Abstract | Publisher Full Text

61. Remacle AG, Cieplak $\mathrm{P}, \mathrm{Nam} \mathrm{DH}$, et al.: Selective function-blocking monoclonal human antibody highlights the important role of membrane type-1 matrix metalloproteinase (MT1-MMP) in metastasis. Oncotarget. 2017; 8(2): 2781-2799. PubMed Abstract | Publisher Full Text | Free Full Text

62. N lizuka S, Quintavalle M, Navarro JC, et al:: Serine-threonine kinase TAO3mediated trafficking of endosomes containing the invadopodia scaffold TKS5 $\alpha$ promotes cancer invasion and tumor growth. Cancer Res. 2021; 81(6): 1472-1485.

PubMed Abstract | Publisher Full Text | Free Full Text | Faculty Opinions Recommendation

63. Quintavalle M, Elia L, Price $\mathrm{JH}$, et al.: A cell-based high-content screening assay reveals activators and inhibitors of cancer cell invasion. Sci Signal. 2011 4(183): ra49.

PubMed Abstract | Publisher Full Text | Free Full Text

64. Gligorijevic B, Wyckoff $\mathrm{J}$, Yamaguchi $\mathrm{H}$, et al:: N-WASP-mediated invadopodium formation is involved in intravasation and lung metastasis of mammary tumors. J Cell Sci. 2012; 125(Pt 3): 724-34.

PubMed Abstract | Publisher Full Text | Free Full Text 
65. Gligorijevic B, Bergman A, Condeelis J: Multiparametric classification links tumor microenvironments with tumor cell phenotype. PLOS Biol. 2014; 12(11): e1001995

PubMed Abstract | Publisher Full Text | Free Full Text |

Faculty Opinions Recommendation

66. Castagnino A, Castro-Castro A, Irondelle M, et al:: Coronin $1 \mathrm{C}$ promotes triplenegative breast cancer invasiveness through regulation of MT1-MMP traffic and invadopodia function. Oncogene. 2018; 37(50): 6425-6441. PubMled Abstract | Publisher Full Text

67. Tönisen F, Perrin L, Bayarmagnai B, et al.: EP4 receptor promotes invadopodia and invasion in human breast cancer. Eur J Cell Biol. 2017; 96(2): 218-226. PubMed Abstract | Publisher Full Text | Free Full Text

68. Williams KC, Cepeda MA, Javed S, et al:: Invadopodia are chemosensing protrusions that guide cancer cell extravasation to promote brain tropism in metastasis. Oncogene. 2019; 38(19): 3598-3615. PubMed Abstract | Publisher Full Text | Free Full Text | Faculty Opinions Recommendation

69. L Leong HS, Robertson $\mathrm{AE}$, Stoletov $\mathrm{K}$, et al.: Invadopodia are required for cancer cell extravasation and are a therapeutic target for metastasis. Cell Rep. 2014; 8(5): 1558-70.

PubMed Abstract | Publisher Full Text | Faculty Opinions Recommendation

70. Lee J, Cabrera AJH, Nguyen CMT, et al:: Dissemination of Ras ${ }^{\mathrm{v} 12}$ transformed cells requires the mechanosensitive channel Piezo. Nat Commun 2020; 11(1): 3568.

PubMed Abstract | Publisher Full Text | Free Full Text | Faculty Opinions Recommendation

71. Quintavalle M, Elia L, Condorelli G, et al:: MicroRNA control of podosome formation in vascular smooth muscle cells in vivo and in vitro. J Cell Biol.
2010; 189(1): 13-22

PubMed Abstract | Publisher Full Text | Free Full Text

Faculty Opinions Recommendation

72. Eckly A, Scandola C, Oprescu A, et al:: Megakaryocytes use in vivo podosome-like structures working collectively to penetrate the endothelial barrier of bone marrow sinusoids. J Thromb Haemost. 2020; 18(11): 2987-3001. PubMed Abstract | Publisher Full Text | Faculty Opinions Recommendation

73. Hagedorn EJ, Ziel JW, Morrissey MA, et al.: The netrin receptor DCC focuses invadopodia-driven basement membrane transmigration in vivo. $J$ Cell Biol. 2013; 201(6): 903-13.

PubMed Abstract | Publisher Full Text | Free Full Text Faculty Opinions Recommendation

74. Osmani N, Goetz JG: Multiscale Imaging of Metastasis in Zebrafish. Trends Cancer. 2019; 5(12): 766-778.

PubMed Abstract | Publisher Full Text | Faculty Opinions Recommendation

75. Sens KL, Zhang S, Jin P, et al:: An invasive podosome-like structure promotes fusion pore formation during myoblast fusion. J Cell Biol. 2010; 191(5): 1013-27.

PubMed Abstract | Publisher Full Text | Free Full Text

76. Kumari A, Pineau J, Sáez PJ, et al:: Actomyosin-driven force patterning controls endocytosis at the immune synapse. Nat Commun. 2019; 10(1): 2870 PubMed Abstract | Publisher Full Text | Free Full Text | Faculty Opinions Recommendation

77. Vorselen D, Wang Y, de Jesus MM, et al:: Microparticle traction force microscopy reveals subcellular force exertion patterns in immune cell-target interactions. Nat Commun. 2020; 11(1): 20 PubMed Abstract | Publisher Full Text | Free Full Text Faculty Opinions Recommendation 